\title{
A needle in a haystack: a multigene TaqMan assay for the detection of Asian gypsy moths in bulk pheromone trap samples
}

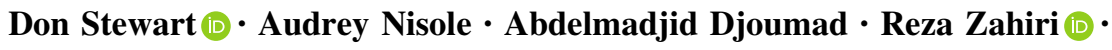 \\ Josyanne Lamarche $\cdot$ Roger C. Levesque $\cdot$ Richard C. Hamelin • \\ Michel Cusson $(1)$
}

Received: 29 August 2018/Accepted: 10 February 2019/Published online: 7 March 2019

(C) The Author(s) 2019

\begin{abstract}
The Asian gypsy moth (AGM) is considered a very serious invasive threat in North America. For this reason, it is subjected to a bio-surveillance program that includes an extensive network of pheromone traps. For regulatory purposes, the term "AGM" designates a group of Asian Lymantria species and subspecies, comprising two $L$. dispar subspecies (L.d. asiatica and L.d. japonica), and three closely related species (L. umbrosa, L. albescens and L. postalba). These moths are attracted to the same pheromone as the European gypsy moth (EGM), $L$.
\end{abstract}

Electronic supplementary material The online version of this article (https://doi.org/10.1007/s10530-019-01943-9) contains supplementary material, which is available to authorized users.

D. Stewart · A. Nisole · A. Djoumad .

J. Lamarche · M. Cusson ( $\square)$

Laurentian Forestry Centre, Canadian Forest Service,

Natural Resources Canada, Quebec City, QC, Canada

e-mail: michel.cusson@canada.ca

R. Zahiri

Ottawa Plant Laboratory, Entomology Unit, Canadian

Food Inspection Agency, Ottawa, ON, Canada

R. C. Levesque · R. C. Hamelin · M. Cusson

Institut de Biologie Intégrative et des Systèmes (IBIS),

Université Laval, Québec, QC, Canada

R. C. Hamelin

Department of Forest and Conservation Sciences, Faculty of Forestry, University of British Columbia, Vancouver, BC, Canada dispar dispar, which is already established in North America and typically makes up the bulk of moths caught in gypsy moth pheromone traps. These different Lymantria taxa are difficult to distinguish from one another using morphological characters alone. Here, we designed a TaqMan triplex assay capable of detecting AGM in bulk pheromone trap samples. The assay targets SNPs found in three different mitochondrial genes. Using a DNA dilution series, we show that the assay can detect AGM taxa at AGM:EGM dilution ratios $\geq 1: 1000$. The assay was validated using batch DNA extractions of moth legs tested at a 1:100 AGM:EGM leg ratio, a proportion that is around the operational limit for a single pheromone trap. The assay provided correct identification for all AGM taxa tested. An experiment examining the integrity of DNA extracted from gypsy moths left in pheromone traps under field conditions for up to 4 months indicated that DNA quality remains sufficient, during that period, for the present assay to remain accurate.

Keywords Asian gypsy moth - Lymantria dispar . Molecular identification · Bulk assay · TaqMan 


\section{Introduction}

The gypsy moth, Lymantria dispar (Linnaeus) (Lepidoptera: Erebidae: Lymantriinae), is considered a major threat to North America's forest resources and economy. This species comprises three recognized subspecies, including the European gypsy moth (EGM), L. dispar dispar (Linnaeus), which is found over most of continental Europe and north-western Africa (Pogue and Schaefer 2007). EGM was accidentally introduced in Massachusetts in 1869 (Liebhold et al. 1989) and has since become established in north-eastern North America, where it is responsible for recurrent and substantial defoliation resulting in important economic losses (Bradshaw et al. 2016). The other two subspecies, L. dispar asiatica Vnukovskij and L. dispar japonica (Motschulsky), are found throughout mainland eastern Asia and Japan, respectively (Pogue and Schaefer 2007). Along with three closely related Lymantria species (L. umbrosa Butler, L. albescens Hori and Umeno, and L. postalba Inoue), they form a complex informally known as Asian gypsy moth (AGM). As a group, these insects are considered a much more serious threat than the European subspecies, in large part because AGM females, unlike those of $L$. dispar dispar, are flightcapable, increasing the probability of a rapid invasion following an unchecked accidental introduction. Such introductions have indeed occurred in the past, but eradication operations appear to have been successful (APHIS 2016; Nealis 2002, 2009).

Molecular markers and diagnostic tools targeting the gypsy moth have become important to help prevent invasions via early intervention (Arimoto and Iwaizumi 2014; Armstrong and Ball 2005; Armstrong et al. 2003; Ball and Armstrong 2006; Bogdanowicz et al. 1993, 1997, 2000; Boykin et al. 2012; Chen et al. 2013, 2015; deWaard et al. 2010; Garner and Slavicek 1996; Harrison and ODell 1989; Islam et al. 2015; Kang et al. 2015, 2017; Keena et al. 2008; Lacković et al. 2015; Pfeifer et al. 1995; Qian et al. 2014; Stewart et al. 2016; Wu et al. 2015). Given that egg masses and larvae of gypsy moth subspecies are impossible to distinguish from one another and from those of other closely related species, we recently developed a suite of TaqMan assays that enables the rapid and accurate identification of 10 Lymantria species and subspecies from intercepted egg masses and older life stages (Stewart et al. 2016). These assays were designed for the processing of individual samples, regardless of their life stage, during inspection or surveys. However, they are not optimal for processing bulk pheromone trap samples, inasmuch as the capture of an AGM is a rare event in North America, where specimens are typically all $L$. dispar dispar. Detection of a single AGM specimen in such samples would be laborious if all moths were to be assayed individually. For this reason, only a fraction of the moths caught in a given trap are processed for identification in current survey procedures, which could result in a failure to detect the presence of AGM (i.e., false negatives).

To tackle this issue, we developed a triplex TaqMan assay that can be used on bulk samples, with the objective of achieving sensitivity levels sufficient to detect one AGM in a background of 1000 EGMs. We modified our previously published suite of assays (Stewart et al. 2016) to ensure that AGM species and subspecies could be discriminated against EGM in a single reaction. This required that we identify markers enabling the design of not only discriminatory probes, but also discriminatory primers for each of the three subassays targeting different AGM taxa. The tool we developed will prove very useful to perform largescale screening for AGM adults in traps and provide early warning of ingress.

\section{Materials and methods}

SNP validation

A scan of the SNP data presented in Djoumad et al. (2017) enabled the identification of markers in cytochrome $\mathrm{b}(\mathrm{cyt} b)$ and NADH-ubiquinone oxidoreductase chain 1 (NDI) potentially suitable for distinguishing the two Asian L. dispar subspecies (treated here together) and L. umbrosa, respectively, from the other AGM taxa. However, selection of these SNPs was based on a very small sample of mitochondrial genome sequences. To increase confidence in the suitability of these markers for species discrimination, sequences gleaned from Djoumad et al. (2017) were aligned with corresponding cytb and ND1 sequences from $L$. dispar [69 cytb sequences (Wu et al. 2015); Popset 756785935) and 19 ND1 sequences (Lin and Zhu, Genbank submissions, accession numbers JX133717 - JX133736)]. We also amplified and sequenced the appropriate region of the NDl gene 
from additional L. umbrosa specimens provided by RZ, using primers and PCR conditions described in Djoumad et al. (2017). The cytochrome c oxidase I (COI) marker used for discrimination of L. albescens and L. postalba (treated here together) from other AGM taxa were the same as those employed by Stewart et al. (2016).

\section{Sources of specimens used}

For the purpose of developing the assay and conducting initial dilution tests, we used DNA extracts from Lymantria specimens generated in the context of an earlier study (Stewart et al. 2016); see Table 1 for details on sample origins and providers. For assay validation, fresh $L$. dispar dispar male moths were collected in Canada using pheromone traps (milkcarton type; Distribution Solida, Saint-Ferréol-lesneiges, Canada) containing a Vaportape II insecticidal strip (Dichlorvos 10\%, Hercon Environmental, Emigsville, USA) and a gypsy moth pheromone dispenser ((+) Disparlure, Trécé Inc., Adair, USA). The traps were suspended from trees at a height of $\sim 1.5 \mathrm{~m}$, from 15 June to 15 September 2017 . Moths were collected and stored in glassine envelopes at $-20{ }^{\circ} \mathrm{C}$ until used.

One hundred $L$. dispar dispar moths were sampled from each of four collection sites, three in the province of Quebec and one in the province of Ontario, for a total of 400 moths. Two parallel assays were conducted for each of the four sets of 100 moths. In the first assay, we used one leg from each $L$. dispar dispar specimen, while for the second assay we used another leg from the same 100 specimens, plus a single AGM leg (from either L. dispar japonica, L. dispar asiatica, L. albescens or L. umbrosa; see Table 2 for sources). The legs were collected in $2 \mathrm{~mL}$ round-bottom Eppendorf safe-lock tubes and placed at $-20{ }^{\circ} \mathrm{C}$ until used.

\section{DNA batch extraction}

DNA was extracted from each batch of legs (30-50 mg of tissue) using the DNeasy Blood and Tissue Mini Kit (Qiagen, Valencia, CA). A $5 \mathrm{~mm}$ stainless steel bead was added to the moth legs in each $2 \mathrm{~mL}$ tube. The tubes were then flash-frozen in liquid nitrogen and placed at $-80{ }^{\circ} \mathrm{C}$ in a prechilled Tissuelyser block. Liquid nitrogen disruption was used to maximize the likelihood that all legs would be sufficiently disrupted to produce similar yields of DNA, as we were not confident that we would achieve this goal with the micro pestle method. The samples were disrupted using a Qiagen Tissuelyser (Qiagen, Valencia, CA) at a speed of $26 \mathrm{~Hz}$ for $60 \mathrm{~s}$ to produce a fine powder. Buffer ATL $(1080 \mu \mathrm{L})$ and proteinase $\mathrm{K}(120 \mu \mathrm{L})$ were then added to each tube, followed by vortexing. The samples were incubated overnight at $56{ }^{\circ} \mathrm{C}$ with constant gentle mixing, using a Robbins Scientific Model 400 Hybridization oven set at $4 \mathrm{rpm}$. After incubation, samples were vortexed and transferred to individual $15 \mathrm{~mL}$ Falcon tubes. Buffer AL
Table 1 Lymantria specimens used for assay development

\begin{tabular}{lllll}
\hline Specimen ID & Species/subspecies & Country of origin & Region & Supplier \\
\hline CFS-0008 & L. dispar dispar & Russia & Krasnoyarsk & M. Keena \\
CFS-0009 & L. dispar asiatica & Russia & Primorsky Krai & M. Keena \\
CFIA-LEP-1724 & L. umbrosa & Japan & Hokkaido & D. Holden \\
CFIA-LEP-1696 & L. albescens & Japan & Okinawa Island & D. Holden \\
\hline
\end{tabular}

Table 2 Asian gypsy moth specimens used for assay validation

\begin{tabular}{lllll}
\hline Specimen ID $^{\mathrm{a}}$ & Species/subspecies & Country of origin & Region & Supplier \\
\hline- & L. dispar japonica & Japan & Honshu & M. Keena \\
- & L. dispar asiatica & China & Beijing & M. Keena \\
CFIA-LEP-0452 & L. umbrosa & Japan & Hokkaido & R. Zahiri \\
CFS-0016 & L. albescens & Japan & Okinawa-Jimi island & D. Holden \\
\hline
\end{tabular}

${ }^{\mathrm{a}} L$. dispar asiatica and $L$. dispar japonica specimens came from lab colonies and were not given an individual label 
$(1200 \mu \mathrm{L})$ was added to the tubes and vortexed, followed by addition of $1200 \mu \mathrm{L}$ of $100 \%$ ethanol and vortexing. For each sample, the lysate was split and transferred to two $2 \mathrm{~mL}$ Eppendorf safe-lock tubes and centrifuged at $5000 \mathrm{rpm}$ for $1 \mathrm{~min}$ to pellet the debris. The cleared lysates were then added to two spin columns (DNeasy Mini spin columns; Qiagen, Valencia, CA) in three steps of $600 \mu \mathrm{L}$, and centrifuged at $8000 \mathrm{rpm}$ for $1 \mathrm{~min}$ after each addition of lysate. The wash steps with buffers AW1 and AW2 were performed according to the manufacturer's instructions. For each sample, DNA was eluted from the two spin columns using $150 \mu \mathrm{L}$ of buffer AE each. The eluted DNA was recovered and then passed through the column a second time; eluates from the two columns were subsequently combined for a final volume of $300 \mu \mathrm{L}$ DNA per sample. The DNA was quantified on a Nanodrop ND-100 spectrophotometer (ThermoFisher Scientific).

Primer and probe design

Primers and probes were designed using the Oligo Explorer program (http://www.genelink.com/tools/gldownloads.asp), except for "locked nucleic acid" (LNA) probes, which were designed using the IDT Biophysics design tool (http://biophysics.idtdna.com/ ). The latter were employed to increase sensitivity and specificity of annealing in cases where probe-based discrimination was provided by a single SNP; a triplet of LNA nucleotides surrounding a single base mismatch site tends to maximize probe specificity (Owczarzy et al. 2011). Similarly, we used "Amplification Refractory Mutation System” (ARMS) primers whenever only one discriminatory SNP was available for primer design. With this approach, an artificial ARMS SNP can be added adjacent to an existing $3^{\prime}$-end SNP, at either position 2 or 3 of the primer, to significantly increase the discriminatory ability of that primer (Newton et al. 1989). ARMS primer combinations were tested against non-ARMS primer pairs to determine the combination that gave the best discrimination against non-target species while having a minimal effect on the specificity of the target species amplification. Primer and probe sequences are provided in Table 3.
qPCR conditions for copy number determination

Optimal performance of the TaqMan assay described here requires that DNA concentrations be normalized. To this end, we quantified COI copy number using a quantitative real-time PCR (qPCR) approach and primers targeting $\mathrm{COI}$ (Table 3). qPCR was performed using an Applied Biosystems 7500 Fast Real Time PCR machine. 96-well MicroAmp Fast Optical real-time PCR plates were used (Applied Biosystems, Foster City, CA) with MicroAmp Optical Adhesive Film (Applied Biosystems, Foster City, CA). The $10 \mu \mathrm{L}$ amplification reactions contained $1 \mu \mathrm{L}$ of DNA and $500 \mathrm{nM}$ of primers. PCR conditions were as follows: a 15-min initial denaturation step at $95{ }^{\circ} \mathrm{C}$ for enzyme activation, followed by 50 cycles of $95{ }^{\circ} \mathrm{C}$, $15 \mathrm{~s} ; 58{ }^{\circ} \mathrm{C}, 30 \mathrm{~s} ; 65^{\circ} \mathrm{C}, 90 \mathrm{~s}$. PCR was performed using the Qiagen Quantitect SYBR Green PCR Kit (Qiagen, Valencia, CA). Two technical replicates were run for each sample. DNA copy number was calculated using the linear regression of efficiency (LRE) approach (Rutledge 2011).

TaqMan conditions for AGM detection in bulk samples

The TaqMan assays were performed using the same equipment as described above. The assays were tested in simplex and triplex formats using the Quantitect Multiplex PCR No Rox 2X Mastermix (Qiagen, Valencia, CA). Final primer and probe concentrations were set at $500 \mathrm{nM}$ and $100 \mathrm{nM}$, respectively, in a $10 \mu \mathrm{L}$ reaction volume. The $L$. dispar asiatica/ $L$. dispar japonica cytb probe was an LNA probe, with a fluorescein (6-FAM) label at the $5^{\prime}$ end and an Iowa Black FQ quencher at the $3^{\prime}$ end. The L. umbrosa ND1 probe was an LNA probe with a HEX label at the $5^{\prime}$ end and an Iowa Black FQ quencher at the $3^{\prime}$ end. The L. albescens/L. postalba COI probe was labelled at the $5^{\prime}$ end with Cy5 and was a double quenched Tao probe with an Iowa Black RQ quencher at the $3^{\prime}$ end (Integrated DNA Technologies, Coralville, IA). Two $\mu \mathrm{L}$ of $L$. dispar dispar DNA (equivalent to 500,000 COI copies) was used for each reaction. PCR conditions for the TaqMan reactions were as follows: a 15-min initial denaturation step at $95{ }^{\circ} \mathrm{C}$ for enzyme activation, followed by 45 cycles of $95^{\circ} \mathrm{C}, 15 \mathrm{~s}$; $60{ }^{\circ} \mathrm{C}, 90 \mathrm{~s}$. Three technical replicates were run for each sample. 
Table 3 Primers and probes used for AGM detection in bulk samples

\begin{tabular}{|c|c|c|c|c|c|}
\hline $\begin{array}{l}\text { Primer/probe } \\
\text { use }\end{array}$ & Primer/probe name & $\begin{array}{l}\text { Primer/probe } \\
\text { sequence }\end{array}$ & $\begin{array}{l}\text { Primer/probe } \\
\text { length (bp) }\end{array}$ & $\begin{array}{l}\text { Primer/probe Tm } \\
\left({ }^{\circ} \mathrm{C}\right)\end{array}$ & $\begin{array}{l}\text { Amplicon } \\
\text { size (bp) }\end{array}$ \\
\hline \multirow[t]{4}{*}{$\begin{array}{l}\text { DNA } \\
\text { quantification }\end{array}$} & $\begin{array}{l}\text { COI Bulk GEN F306- } \\
327^{1}\end{array}$ & $\begin{array}{l}\text { TAGAAAATGGAG } \\
\text { CAGGAACAGG }\end{array}$ & 22 & 59.9 & \\
\hline & $\begin{array}{l}\text { COI Bulk GEN17W } \\
\text { R399-4241 }\end{array}$ & $\begin{array}{l}\text { TGATGAAATWCC } \\
\text { AGCTAAGTGAAG } \\
\text { AG }\end{array}$ & 26 & 59.9 & 118 \\
\hline & $\begin{array}{l}\text { Lalb COI } \\
\text { F497-520² }\end{array}$ & $\begin{array}{l}\text { CCTTTATTTGTTT } \\
\text { GAAGAGTAGGT }\end{array}$ & 24 & 55.2 & \\
\hline & $\begin{array}{l}\text { Lalb COI } \\
\text { R562-585² }\end{array}$ & $\begin{array}{l}\text { GTTAATAATATTG } \\
\text { TAATAGCACCC }\end{array}$ & 24 & 52.8 & 88 \\
\hline \multirow[t]{3}{*}{$\begin{array}{l}\text { Detection of } \\
\text { L. umbrosa }\end{array}$} & $\begin{array}{l}\text { Lumb ND1 3C/A } \\
\text { F233-262 }\end{array}$ & $\begin{array}{l}\text { TATTTTTCTCCTGT } \\
\text { ATTAGCTTTTGAT } \\
\text { A }^{3}\end{array}$ & 28 & 57.9 & \\
\hline & $\begin{array}{l}\text { Lumb ND1 2C/T } \\
\text { R375-395 }\end{array}$ & $\begin{array}{l}\text { GAATTAGAAGAC } \\
\text { CATCCTGTC }\end{array}$ & 21 & 58.9 & 127 \\
\hline & $\begin{array}{l}\text { Lumb ND1 } \\
\text { T340-358 R/C } \\
(\mathrm{HEX}-\mathrm{LNA})^{4}\end{array}$ & $\begin{array}{l}\mathrm{AC}+\mathrm{A}+\mathrm{CTATAAA}+ \\
\mathrm{C}+\mathrm{T}+\mathrm{CCAAAAC}{ }^{5}\end{array}$ & 19 & 58.9 & \\
\hline \multirow[t]{3}{*}{$\begin{array}{l}\text { Detection of } \\
\text { L. albescens \& } \\
\text { L. postalba }\end{array}$} & $\begin{array}{l}\text { Lalb COI F3G/A F491- } \\
520\end{array}$ & $\begin{array}{l}\text { CAAATACCTTTAT } \\
\text { TTGTTTGAAGAGT } \\
\text { AAGT }\end{array}$ & 30 & 56.6 & \\
\hline & $\begin{array}{l}\text { Lalb COI R2C/A R562- } \\
590\end{array}$ & $\begin{array}{l}\text { GGTCAGTTAATAA } \\
\text { TATTGTAATAGCA } \\
\text { CAC }\end{array}$ & 29 & 58.4 & 100 \\
\hline & $\begin{array}{l}\text { Lalb COI T } \\
525-552 \\
(T A O-C Y 5)^{4}\end{array}$ & $\begin{array}{l}\text { CAGCTTTCCTTCT } \\
\text { ACTTTTATCATTA } \\
\text { CC }\end{array}$ & 28 & 59.9 & \\
\hline \multirow[t]{3}{*}{$\begin{array}{l}\text { Detection of } \\
\text { L. dispar } a .+j .{ }^{6}\end{array}$} & $\begin{array}{l}\text { Ldaj cytb 3A/T F120- } \\
150\end{array}$ & $\begin{array}{l}\text { GGATCTTTGTTAG } \\
\text { CTTTATGTTTAATT } \\
\text { TCC }\end{array}$ & 30 & 58.6 & \\
\hline & $\begin{array}{l}\text { Ldaj } c y t b \\
\text { R339-369 }\end{array}$ & $\begin{array}{l}\text { TCCAATTATTCAT } \\
\text { GTTTGTTTTAAAT } \\
\text { TAAAA }\end{array}$ & 31 & 51.4 & 240 \\
\hline & $\begin{array}{l}\text { Ldaj cytb } \\
\text { T262-273 } \\
\text { (FAM - LNA) }^{4}\end{array}$ & $\begin{array}{l}\mathrm{CT}+\mathrm{CT}+\mathrm{TC}+\mathrm{A}+\mathrm{C}+ \\
\mathrm{G}+\mathrm{CT}\end{array}$ & 11 & 58.7 & \\
\hline
\end{tabular}

\footnotetext{
${ }^{1}$ These primers will amplify DNA from $L$. dispar dispar, L. dispar asiatica, L. dispar japonica and L. umbrosa. They can be used to quantify bulk DNA extracts, which will typically contain only or mostly $L$. dispar dispar DNA

${ }^{2}$ These primers are used to quantify L. albescens/L. postalba DNA

${ }^{3}$ Sequences containing a red character are ARMS primers, where the red letter represents the introduced mismatch ${ }^{4}$ In brackets: probe type

${ }^{5}$ In probe sequences (blue letters), bases preceded by a “+” sign are LNA bases

${ }^{6} L$. dispar $a .+j .=L$. dispar asiatica and $L$. dispar japonica
} 
Table 4 Primers used for L. dispar dispar DNA amplification, for the purpose of assessing DNA integrity over time

\begin{tabular}{llll}
\hline Primer name & Primer sequence & Primer length $(\mathrm{bp})$ & Primer $\mathrm{Tm}\left({ }^{\circ} \mathrm{C}\right)$ \\
\hline Ldd COI 8R F487-513 & TGATCAAATACCTTTATTTRTTTGAAG & 27 & $53.2 / 51.0$ \\
Ldd COI R574-603 & GTATTTAAATTTCGGTCAGTTAATAATATT & 30 & 52.5 \\
FS1 F2-16 & GATGGTGGGTGTCGT & 15 & 54.9 \\
FS1 R176-200 & GATTCATCTGATCCTGATAATTCAT & 25 & 54.9 \\
\hline
\end{tabular}

Assessing DNA integrity in pheromone trap samples

Since the assay we developed is meant to be used on samples containing moths that have resided in pheromone traps for various periods of time under field conditions, we wanted to determine whether the quality of DNA extracted from such moths was sufficient to ensure reliable molecular identification. Because we did not have access to fresh AGM specimens, we ran this experiment using $L$. dispar dispar moths only, with the assumption that DNA stability in dead moths will be comparable for all gypsy moth subspecies.

Freshly killed $L$. dispar dispar male moths were obtained from Insect Production Services (Natural Resources Canada, Sault Ste. Marie, Ontario) and placed in six delta bi-directional insect sticky traps (Better World Manufacturing, Fresno, California) on May 20, 2016, at a density of 5-6 moths/trap. The traps were suspended on spruce trees $\sim 3 \mathrm{~m}$ above ground, in a semi-wooded area on the Laurentian Forestry Centre property in Quebec City, Canada. Moths were then collected on a monthly basis, between May and September, and frozen at $-20{ }^{\circ} \mathrm{C}$ until used; time-zero samples were placed directly in the freezer. DNA was extracted from two legs (or head plus thorax, if legs were absent), using the Qiagen DNeasy Blood and Tissue Mini Kit protocol, according to the manufacturer's instructions. The tissue disruption step was performed in $180 \mu \mathrm{L}$ buffer ATL using a micro-pestle.

The PCR primers used are those designed by Stewart et al. (2016) for EGM detection (i.e., subassays 3A, 4A and 4B). One pair is specific to the $L$. dispar dispar mitochondrial COI gene while the other is specific to the nuclear FS1 marker (Table 4). DNA was quantified and diluted to $2.5 \mathrm{ng} / \mu \mathrm{L}$, and $\mathrm{qPCR}$ reactions were run using $5 \mathrm{ng}$ of genomic DNA. $\mathrm{C}_{t}$ values for both mitochondrial $(\mathrm{COI})$ and nuclear (FS1) DNAs were monitored over time, and the $C_{t}$ ratio calculated to determine if mitochondrial DNA was more stable than nuclear DNA, as expected. The qPCR conditions were similar to those described above for copy number determination (initial 15 min denaturation step at $95{ }^{\circ} \mathrm{C}$, followed by 50 cycles of $95^{\circ} \mathrm{C}$, $\left.15 \mathrm{~s} ; 50{ }^{\circ} \mathrm{C}, 30 \mathrm{~s} ; 65^{\circ} \mathrm{C}, 90 \mathrm{~s}\right)$.

\section{Results}

Assay development

To achieve our goal of designing a multiplex assay that could be conducted in a single tube, we treated as a single taxon each of two taxon pairs, namely $L$. dispar asiatica and L. dispar japonica, and L. albescens and L. postalba, given the high within-pair similarity observed in their mitogenomes (Djoumad et al. 2017; Djoumad et al. unpublished data).

\section{Bulk triplex A subassay}

Among the primers and probes developed by Stewart et al. (2016), the set developed for $L$. albescens/L. postalba, targeting $\mathrm{COI}$, was directly transferable to this assay as it met our requirements for speciesspecificity and dual primer/probe-based discriminatory capabilities. Species discrimination was here provided by two ARMS primers and a probe (for details, see Fig. 2 under the "Bulk Triplex A" tab of Online Resource 1). However, for the other two subassays (see below), new primers and probes had to be designed from alternative marker genes, as sufficient discriminatory SNPs for primer development could not be found in the COI gene. 


\section{Bulk triplex B subassay}

For the L. dispar asiatica/L. dispar japonica taxon pair, analysis of the mitochondrial genome sequences reported by Djoumad et al. (2017) led to the identification of discriminatory SNPs in the $c y t b$ gene. Comparison of this target sequence with equivalent sequences gleaned from public databases indicated that inter-individual sequence homogeneity of the $c y t b$ gene in L. dispar asiatica and L. dispar japonica was sufficient to yield discriminatory amplification; discrimination was here provided by a forward ARMS primer and an LNA probe (Fig. 1, alignment provided as an example; see also Fig. 3 under the "Bulk Triplex B" tab of Online Resource 1).

\section{Bulk triplex C subassay}

With respect to L. umbrosa, an analytical approach similar to the one described above for the selection of cytb pointed to ND1 as the most likely source of SNPs that would enable discrimination of this species from other taxa. As no L. umbrosa NDI sequences other than the one we had reported (Djoumad et al. 2017) were available in public databases, inter-individual sequence stability was confirmed through the sequencing of this region from additional specimens. For this subassay, discrimination was provided by two ARMS primers and an LNA probe (see Fig. 2 under "Bulk Triplex C" tab of Online Resource 1).

\section{Initial tests of the bulk assay using DNA dilution series}

As a first assessment of the performance of the bulk assay, tests were conducted in both simplex and triplex formats, using DNA dilution series. For example, 1000, 100, 10 and 0 COI copies of L. albescens DNA were assayed alone or in combination with 1 million COI copies of $L$. dispar dispar DNA, generating dilution ratios of $1: 10^{3}, 1: 10^{4}, 1: 10^{5}$ and $0: 10^{6}$. Amplification curves observed in the presence of $L$. dispar dispar DNA were similar to those generated by L. albescens DNA alone, at all three non-zero dilutions tested (Fig. 2a; simplex format), indicating that this

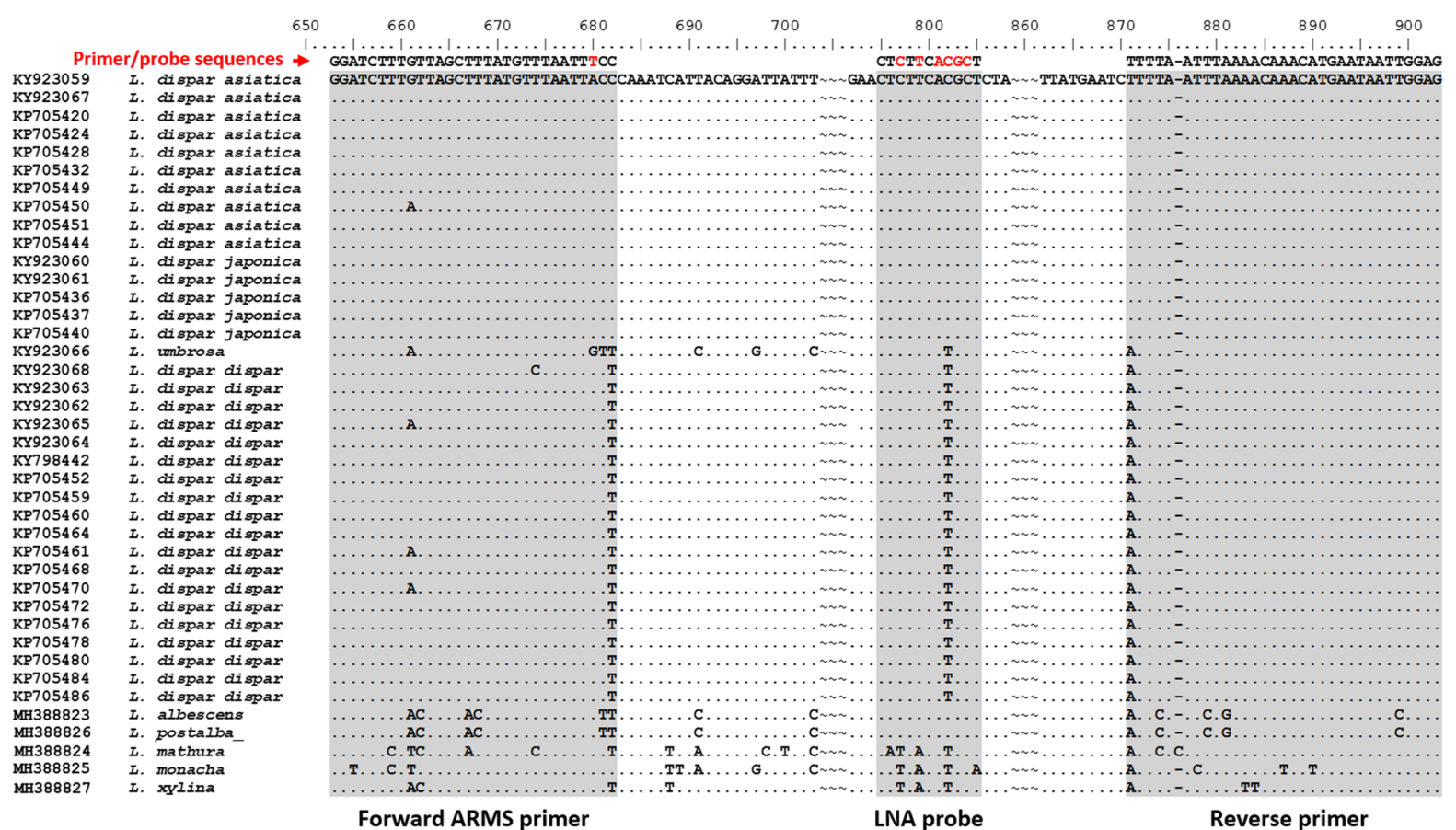

Fig. 1 Alignment of the portion of the $c y t b$ gene used to design primers and probes for development of a TaqMan assay that can detect DNA from either Lymantria dispar asiatica or L. dispar japonica, when mixed with DNA from $L$. dispar dispar and/or other Lymantria species. Sequences shown at the top of the grey bars are (from left to right) those of the forward primer, probe and reverse primer. Red letters: ARMS base in forward primer and LNA bases in probe. Left-most column: Genbank accession numbers; cytb sequences for $L$. albescens, L. postalba, $L$. mathura, L. monacha and L. xylina were generated within the context of a separate, ongoing study (Djoumad et al., unpublished data) 

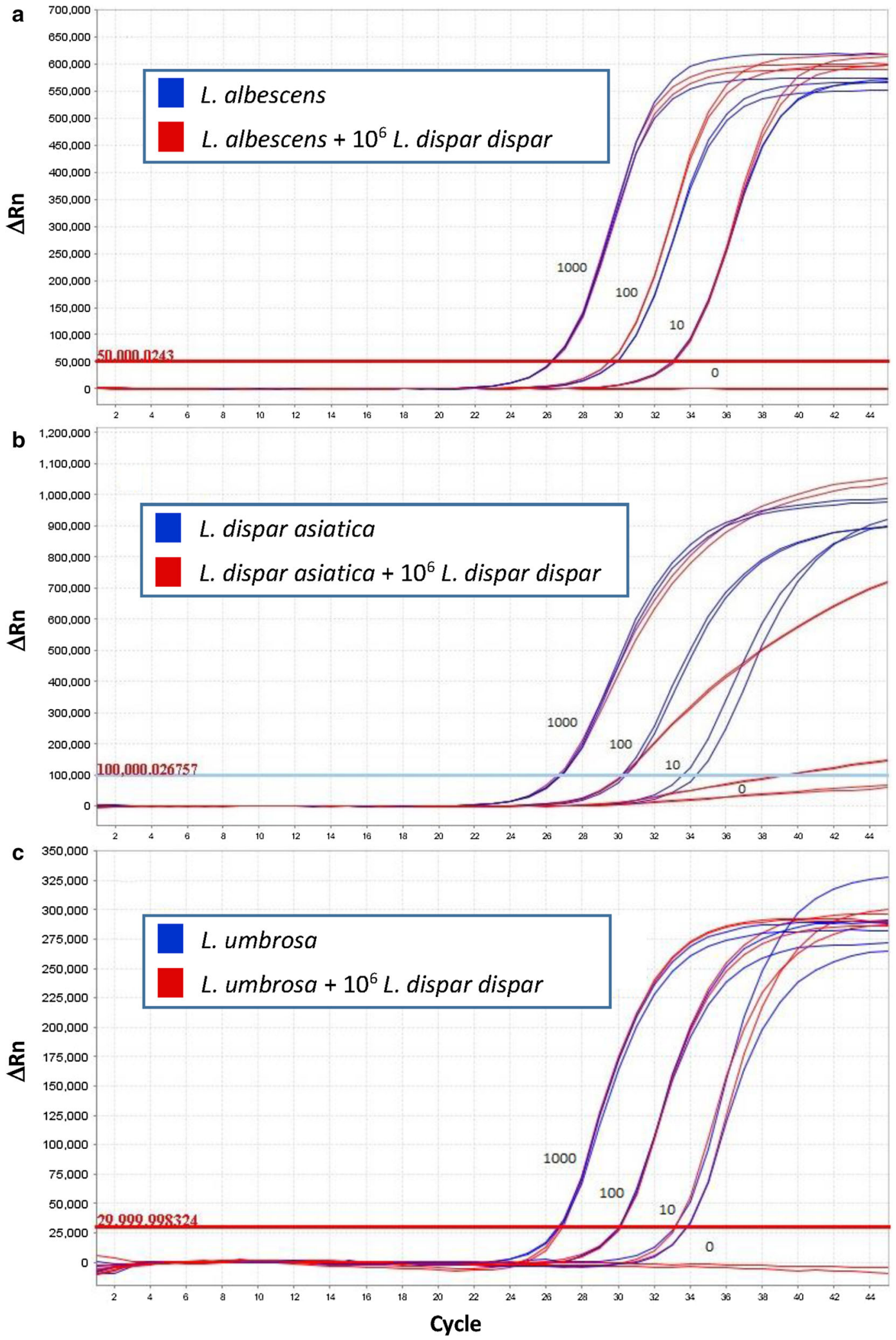
4Fig. 2 Assessment of the sensitivity of each TaqMan subassay through dilution of target species DNA. A dilution series of 1000, 100 and 10 COI copies of a L. albescens (LYM01 sample), b $L$. dispar asiatica (CFS9 sample), and c $L$. umbrosa (CFIA-LEP1724 sample) was run in simplex mode, with (red) and without (blue) a background of one million COI copies of $L$. dispar dispar (CFS8 sample). Two technical replicates are shown for each assay

subassay could detect 1 L. albescens specimen against a background of 100,000 L. dispar dispar moths. No amplification was observed when $10^{6} \mathrm{COI}$ copies of $L$. dispar dispar DNA were assayed alone, indicating that the primers and probe designed for this subassay are highly specific to $L$. albescens. Similar results were obtained in triplex mode (see Table 1 under "Bulk Triplex A" tab of Online Resource 1). The Bulk Triplex B subassay, targeting $L$. dispar asiatica and $L$. dispar japonica, provided complete discrimination against $L$. dispar dispar at a 1:1000 dilution (i.e., $10^{3}: 10^{6}$ ), but its performance gradually declined at higher dilutions (Fig. 2b; simplex format). Comparable results were obtained in triplex format as well as in tests involving alternative dilution series run in simplex format (see "Bulk Triplex B" tab of Online Resource 1). Finally, the Bulk Triplex C subassay, which targets L. umbrosa, showed a degree of sensitivity similar to that obtained with the Bulk Triplex A subassay (Fig. 2c; simplex format). Again, assay performance was equally good when run in triplex format (see Table 1 under the Bulk Triplex C tab of Online Resource 1).

Assay validation

To validate the present assay using DNA extracts from different moths (as opposed to varying proportions of DNA used, as in the above dilution series), we used DNA extracted from $100 \mathrm{~L}$. dispar dispar legs (1 leg/moth), either alone or in combination with a leg from an AGM specimen (L. dispar asiatica, L. dispar japonica, L. albescens or L. umbrosa), resulting in a 1:100 AGM:EGM leg ratio. No amplification was observed for any of the four negative controls ( $L$. dispar dispar alone, obtained from four different collection sites; $10^{6}$ COI copies), whereas each of the four test assays generated a positive amplification (Fig. 3; see also Online Resource 2). To determine whether a mixture of AGM taxa present in a given sample could be detected and identified in a single assay, three of the above DNA extracts were combined in equal aliquots, effectively diluting copy number for L. umbrosa, L. albescens and L. dispar asiatica by a factor of three. All three samples generated a speciesspecific, positive amplification (Online Resource 2).

DNA integrity in pheromone trap samples

DNA extracted from L. dispar dispar moths that were left in pheromone traps under field conditions for different periods of time, was assessed for its reliability in an assay such as the one reported here, using qPCR primers developed for EGM detection (Stewart et al. 2016). All of the samples at all of the time points, for both markers tested, yielded positive results for the presence of EGM (Table 5). Overall, the DNA appears to have remained in good condition over the 4 months the insects were left in the traps, as judged by the relative stability of the $\mathrm{C}_{\mathrm{t}}$ values obtained for both $\mathrm{COI}$ and FS1 over time (Table 5). Nonetheless, a slight increase in variation in $\mathrm{C}_{\mathrm{t}}$ values became apparent in months 3 and 4 (T3 and T4), with two samples showing significant shifts (T3-2, COI and FS1; T4-2, FS1; Table 5), suggesting the DNA in these moths had begun degrading at the time they were sampled, albeit not to a degree sufficient to jeopardize the assay. The greater COI:FS1 ratio recorded for these two samples (Table 5) also pointed to the higher stability of mitochondrial DNA, versus nuclear DNA, as predicted.

\section{Discussion}

Detecting an extremely rare invasive species against a background of an abundant, already established close relative is akin to looking for a needle in a haystack. For example, networks of pheromone traps deployed for the detection of AGM can easily produce situations where an AGM individual, if caught, is greatly outnumbered by local EGMs. Unlike other molecular assays designed by others to detect a single species in a large background of another species (e.g., Zink et al. 2017, 2018), the assay reported here had to overcome the additional hurdle of distinguishing taxa within the AGM complex. To this end, we developed independent sets of qPCR primers and TaqMan probes for AGM species/subspecies, using SNPs identified 


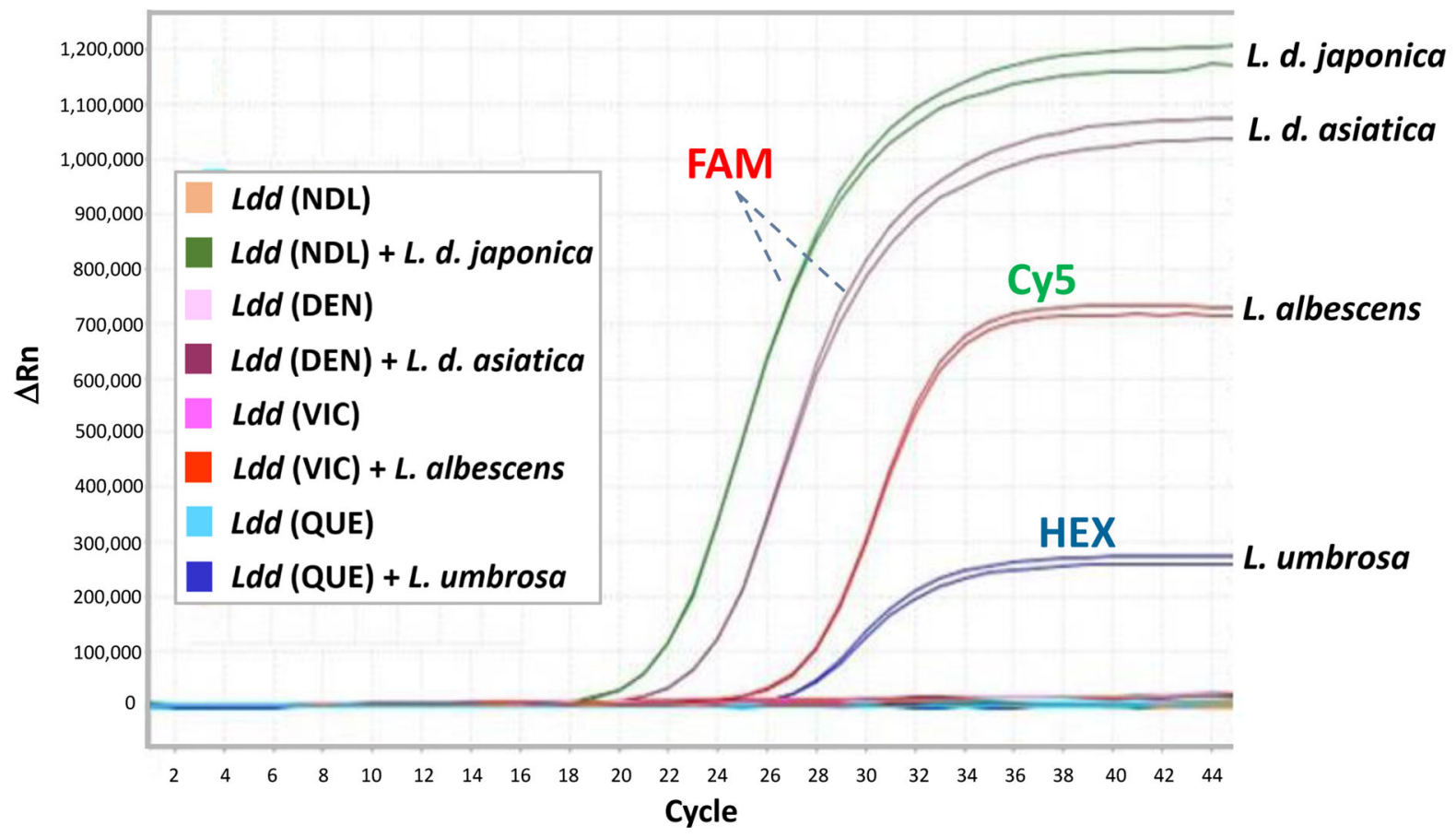

Fig. 3 Validation of the triplex TaqMan assay using DNA extracted from moth legs. The results of eight independent assays, each run in triplex mode, are combined here on a single graph for comparative purposes. For each of four "negative control" assays, we used DNA extracted from 100 legs obtained from $100 \mathrm{~L}$. dispar dispar specimens collected at one of four Canadian locations (Notre-Dame-des-Laurentides, QuebecNDL; Denwood, ON-DEN; Victoriaville, QC-VIC; Quebec City, QC-QUE), while for each of the four "test" assays, we used DNA extracted from 100 legs obtained from the same sets

earlier in three distinct mitochondrial genes (Djoumad et al. 2017). This approach enabled the development of a highly sensitive triplex TaqMan assay capable of detecting a single specimen of $L$. umbrosa or $L$. albescens (or L. postalba) in a background of up to 100,000 L. dispar dispar moths, and a single specimen of $L$. dispar asiatica or $L$. dispar japonica in a background of at least $1000 \mathrm{~L}$. dispar dispar moths, based on DNA dilution series (Fig. 2). In the validation tests we conducted using DNA extracted from batches of moth legs, the above-mentioned AGM taxa were all easily detected when present in a 1:100 AGM:EGM leg ratio (Fig. 3), a proportion believed to be near the maximum to be ever processed operationally. Of course, given that DNA extraction efficiency for such samples may not be uniform among legs, the proportion of DNA from a single AGM leg could, by chance, be lower than that of 100 L. dispar dispar specimens, plus a single AGM leg obtained from either $L$. dispar japonica, $L$. dispar asiatica, $L$. albescens or L. umbrosa (see Table 2 for sources). No amplification was observed for the four negative controls ( $L$. dispar dispar alone), whereas each of the four test assays generated a positive amplification. Differences in fluorescence levels $\left(\mathrm{F}_{\max }\right)$ are the result of different fluorophores being used for probe design: FAM has the highest fluorescence, followed by Cy5 and HEX. Two technical replicates are shown for each assay

suggested by the 1:100 leg ratio. However, given the high sensitivity of this assay ( $\geq 1: 1000$ AGM:EGM, as indicated by the dilution series), the likelihood of a failed AGM detection is very low.

Our operational goal in developing this assay was quite different from the one we pursued in designing our earlier suite of TaqMan assays (Stewart et al. 2016), which targeted individual samples of immature stages of gypsy moths. In an effort to streamline the bulk assay, we did not attempt to identify species other than those considered members of the AGM complex. However, we looked for markers that would enable AGM discrimination against both EGM and other Lymantria species that could accidentally find their way into gypsy moth pheromone traps, including those considered "OTLS" ("other threatening Lymantria species") in our earlier work (Stewart et al. 2016); it should be noted that these OTLS moths are 
Table 5 DNA extraction and $q P C R$ results $\left(C_{t}\right.$ values) for the experiment assessing DNA integrity in moths held under field conditions for different lengths of time

\begin{tabular}{|c|c|c|c|c|c|c|c|}
\hline Sample ID $^{\mathrm{a}}$ & Collection date (2016) & Starting material & DNA conc. $(\mathrm{ng} / \mu \mathrm{L})^{\mathrm{b}}$ & $260: 280^{c}$ & $\begin{array}{l}\text { Mean } \mathrm{C}_{\mathrm{t}} \\
\text { COI }\end{array}$ & $\begin{array}{l}\text { Mean } C_{t} \\
\text { FS1 }\end{array}$ & $\begin{array}{l}\text { Ratio } \\
\text { COI:FS1 }\end{array}$ \\
\hline T0-1 & 20 May & 2 legs & 7.7 & 1.38 & 14.23 & 20.61 & 83.71 \\
\hline T0-2 & 20 May & 2 legs & 8.1 & 1.37 & 14.66 & 20.77 & 69.09 \\
\hline T0-3 & 20 May & 2 legs & 9.8 & 1.39 & 13.91 & 20.79 & 117.48 \\
\hline \multirow[t]{3}{*}{ T0-4 } & 20 May & 2 legs & 5.3 & 1.34 & 13.81 & 20.71 & 119.35 \\
\hline & & & & Average & 14.15 & 20.72 & 97.41 \\
\hline & & & & $\mathrm{CV}$ & $2.7 \%$ & $0.4 \%$ & $25.7 \%$ \\
\hline T1-1 & 21 June & 2 legs & 6.8 & 1.24 & 15.46 & 21.47 & 64.13 \\
\hline $\mathrm{T} 1-2$ & 21 June & 2 legs & 8.9 & 1.42 & 15.95 & 22.77 & 112.91 \\
\hline $\mathrm{T} 1-3$ & 21 June & Head/thorax & 55.4 & 1.85 & 16.56 & 21.24 & 25.62 \\
\hline $\mathrm{T} 1-4$ & 21 June & 2 legs & 11.3 & 1.52 & 15.87 & 21.12 & 38.08 \\
\hline $\mathrm{T} 1-5$ & 21 June & 2 legs & 9.2 & 1.59 & 14.42 & 20.56 & 70.42 \\
\hline \multirow[t]{3}{*}{ T1-6 } & 21 June & Head/thorax & 38.5 & 1.72 & 15.59 & 21.54 & 61.47 \\
\hline & & & & Average & 15.64 & 21.45 & 62.10 \\
\hline & & & & $\mathrm{CV}$ & $4.5 \%$ & $1.9 \%$ & $48.64 \%$ \\
\hline $\mathrm{T} 2-1$ & 21 July & 2 legs & 8.1 & 1.36 & 14.73 & 20.72 & 63.44 \\
\hline $\mathrm{T} 2-2$ & 21 July & 2 legs & 10.5 & 1.68 & 16.11 & 22.53 & 85.51 \\
\hline $\mathrm{T} 2-4$ & 21 July & 2 legs & 9.0 & 1.96 & 14.15 & 20.34 & 73.01 \\
\hline $\mathrm{T} 2-5$ & 21 July & 2 legs & 4.5 & 3.09 & 14.20 & 20.03 & 56.58 \\
\hline \multirow[t]{3}{*}{ T2-6 } & 21 July & 2 legs & 8.4 & 2.04 & 14.84 & 20.57 & 52.94 \\
\hline & & & & Average & 14.81 & 20.84 & 66.30 \\
\hline & & & & $\mathrm{CV}$ & $5.3 \%$ & $5.4 \%$ & $19.9 \%$ \\
\hline T3-1 & 22 Aug & 2 legs & 5.0 & 1.39 & 16.25 & 22.31 & 66.51 \\
\hline T3-2 & 22 Aug & 2 legs & 10.7 & 1.75 & 19.02 & 27.40 & 332.68 \\
\hline T3-4 & 22 Aug & 2 legs & 4.5 & 2.32 & 14.88 & 21.45 & 95.30 \\
\hline T3-5 & 22 Aug & Head/thorax & 62.0 & 1.85 & 16.59 & 20.88 & 19.58 \\
\hline \multirow[t]{3}{*}{ T3-6 } & 22 Aug & 2 legs & 4.0 & 2.35 & 15.91 & 21.72 & 56.43 \\
\hline & & & & Average & 16.53 & 22.75 & 114.10 \\
\hline & & & & $\mathrm{CV}$ & $9.3 \%$ & $13.4 \%$ & $109.7 \%$ \\
\hline $\mathrm{T} 4-2$ & 20 Sept & Head/thorax & 4.2 & 3.63 & 15.93 & 27.50 & 3038.10 \\
\hline $\mathrm{T} 4-4$ & $20 \mathrm{Sept}$ & Head/thorax & 27.2 & 1.98 & 16.18 & 22.32 & 70.63 \\
\hline $\mathrm{T} 4-5$ & $20 \mathrm{Sept}$ & 2 legs & 6.7 & 1.78 & 15.85 & 22.02 & 72.12 \\
\hline \multirow[t]{3}{*}{ T4-6 } & 20 Sept & 2 legs & 6.3 & 2.81 & 14.71 & 20.84 & 70.02 \\
\hline & & & & Average & 15.67 & 23.17 & 812.72 \\
\hline & & & & $\mathrm{CV}$ & $4.2 \%$ & $12.8 \%$ & $182.5 \%$ \\
\hline
\end{tabular}

a Sample ID: T0 to T4 refer to sampling times, while -1 to -6 refer to trap number, except for T0 samples, which were not placed in traps, but transferred directly to the freezer. Samples were taken from trap \#3 only once as birds entered the trap after the June sampling date and destroyed all moths

${ }^{\mathrm{b}}$ This concentration was normalized to $2.5 \mathrm{ng} / \mu \mathrm{L}$ for running the assay

${ }^{\mathrm{c}} 260: 280$ purity ratio

${ }^{\mathrm{d}}$ Calculated using the formula: $2^{\wedge}\left(\mathrm{C}_{\mathrm{t}}^{\mathrm{FS} 1}-\mathrm{C}_{\mathrm{t}}^{\mathrm{COI}}\right)$

morphologically distinguishable from AGM and EGM, although this is not true of all Lymantria species. In addition, we had to make sure that species discrimination, for the present assay, was provided by both primers and probes (as opposed to probe-onlybased discrimination) so as to avoid situations where 
all DNAs in a given bulk sample are amplified evenly, resulting in the drowning of the signal produced by a probe annealing to low-abundance AGM-related DNAs.

Examples of other assays designed for the detection of invasive species in bulk pheromone trap samples include the one developed for the detection of the invasive noctuid Helicoverpa armigera among large numbers of the native congener $H$. zea (Zink et al. 2017), and another one that targets the silver Y moth, Autographa gamma, in a background of several closely related species (Zink et al. 2018). For these two assays, the authors opted for the use of a different, more recent PCR technology known as droplet digital PCR (ddPCR), largely because of its high reported sensitivity (Milbury et al. 2014). Although ddPCR clearly provided excellent performance for these two assays, the level of sensitivity we achieved in the present TaqMan qPCR assay is at least as good as that reported by this group (1:1000, Zink et al. 2017; 1:200, Zink et al. 2018). The qPCR TaqMan assay also has the advantage of requiring a type of thermocycler that is less expensive and more ubiquitous than the ddPCR equipment employed by Zink et al. (2017, 2018). In addition, the work involved in data analysis and interpretation for the present assay is simpler and more easily automated than it is for the ddPCR technology.

The results reported here for the $c y t b$ subassay ( $L$. dispar asiatica/L. dispar japonica), point to the somewhat lower discriminatory power of this assay against $L$. dispar dispar as compared to the other two subassays (Fig. 2), albeit at a level that remains more than adequate (1:1000 AGM:EGM) for operational bulk processing. Several factors are likely involved in the collapse of the AGM-positive curve that we observe at dilutions $>1: 1000$. First, mitochondrial sequences of $L$. dispar dispar show greater overall similarity to those of $L$. dispar asiatica and $L$. dispar japonica than to those of L. umbrosa and L. albescens, resulting in slightly lower primer-based discrimination. Compounding this effect is the significantly larger amplicon generated by this subassay ( $240 \mathrm{bp}$ ) as compared to those produced by the other two subassays (100 and $127 \mathrm{bp}$; see Table 3). Nonetheless, although the primers specific to the $L$. dispar asiatical L. dispar japonica taxon pair likely generate an amplicon in the presence of very high excess $L$. dispar dispar DNA, the specific LNA probe is not expected to efficiently anneal to it.
The mitochondrial genomes of $L$. dispar asiatica and $L$. dispar japonica display a strikingly high degree of sequence similarity (Djoumad et al. 2017), making it very difficult to design a TaqMan assay that could distinguish one subspecies from the other in the context of a procedure meant to process bulk samples. In addition, to keep the present assay simple (i.e., single tube multiplex qPCR), an ability to distinguish the two Asian subspecies would have required that we increase the assay's multiplexing capability to four. For these reasons, we opted for the simpler taxon combination used here, with an understanding that, should any given trap sample generate a positive $L$. dispar asiatica/L. dispar japonica signal, the exact subspecies involved could subsequently be identified through an analysis of DNA extracts from individual moths using our earlier assay (Stewart et al. 2016).

Gypsy moth pheromone traps are typically emptied of their content only at the end of the trapping season. As a consequence, moths recovered at the end of the flight period may have spent up to 3-4 months in the field, exposed to environmental conditions that could be detrimental to DNA integrity. Given that compromised DNA quality could seriously jeopardize the reliability of the present bulk assay, we assessed moth DNA stability under field conditions, using $L$. dispar dispar moths as AGM surrogates. Our results point to a degree of DNA integrity that would be sufficient for the bulk assay to provide accurate species detection when run on moths that have spent up to 4 months in the field, at least under conditions similar to those tested here (Table 5; Online Resource 3). However, some of the samples collected in the second half of the experimental period displayed a somewhat delayed $C_{t}$ relative to early samples, suggesting that their DNA may have begun to lose some of its initial quality. To avoid DNA degradation after field collection, we therefore recommend that samples be frozen until processed for species identification.

It is important to note that the present assay was designed to identify AGM specimens originating from their most likely sources when intercepted in North America, i.e., Japan, South Korea, eastern China and the Russian Far East. Indeed, given that our assay relies on mitochondrial markers, it will not detect specimens from central Asia if they possess an $L$. dispar dispar mitochondrial haplotype, even though their nuclear genomes and some of their biological traits (e.g., female flight capability) may display 
greater similarity to $L$. dispar asiatica than to $L$. dispar dispar, as earlier studies have suggested (Djoumad et al. 2017; Keena et al. 2008; Picq et al. 2018; Stewart et al. 2016; Wu et al. 2015). However, because countries/regions where populations showing this type of inter-subspecies introgression are relatively far from those mentioned above, the likelihood of such AGM-like hybrids finding their way to North America is currently low. Nonetheless, we are now conducting work aimed at identifying nuclear markers that could be added to our current panel and used to identify gypsy moths from central Asia.

Finally, it should be pointed out that, with the advent of three-channel portable qPCR devices, the assay described here could also be used for on-site screening of gypsy moth egg samples intercepted during ship inspections, whenever a rapid answer to the question "is this AGM?" may be required. Such samples could subsequently be re-processed using the Stewart et al. (2016) suite of assays for a more detailed analysis.

Acknowledgements We thank M. Keena (USDA Forest Service), S. Picq (Natural Resources Canada; NRCan), and D. Holden (Canadian Food Inspection Agency; CFIA) for providing specimens used in this study. We are also grateful to V. Nealis (NRCan), who brought to our attention the need for an AGM bulk assay. Finally, we thank J. Delisle, A. Labrecque and S. Picq (NRCan) for providing the weather data presented in the Online Resource 3. This work was funded by Genome Canada, Genome British Columbia, Genome Quebec, the Canadian Forest Service (Genomics Research and Development Initiative, GRDI) and the CFIA, through a Genomics Applications Partnership Program (GAPP 6102; Genome Canada) grant.

Open Access This article is distributed under the terms of the Creative Commons Attribution 4.0 International License (http:// creativecommons.org/licenses/by/4.0/), which permits unrestricted use, distribution, and reproduction in any medium, provided you give appropriate credit to the original author(s) and the source, provide a link to the Creative Commons license, and indicate if changes were made.

\section{References}

Arimoto M, Iwaizumi R (2014) Identification of Japanese Lymantria species (Lepidoptera: Lymantriineae) based on PCR-RFLP analysis of mitochondrial DNA. Appl Entomol Zool 49:159-169
Armstrong KF, Ball SL (2005) DNA barcodes for biosecurity: invasive species identification. Philos Trans R Soc B Lond 360:1813-1823

Armstrong KF, McHugh P, Chinn W, Frampton ER, Walsh PJ (2003) Tussock moth species arriving on imported used vehicles determined by DNA analysis. NZ Plant Prot 56:16-20

Ball SL, Armstrong KF (2006) DNA barcodes for insect pest identification: a test case with tussock moths (Lepidoptera: Lymantriineae). Can J For Res 36:337-350

Bogdanowicz SM, Wallner WE, Bell J, Odell TM, Harrison RG (1993) Asian gypsy moths (Lepidoptera: Lymantriineae) in North America: evidence from molecular data. Ann Entomol Soc Am 86:710-715

Bogdanowicz SM, Mastro VC, Prasher DC, Harrison RG (1997) Microsatellite DNA variation among Asian and North American gypsy moths (Lepidoptera: Lymantriineae). Ann Entomol Soc Am 90:768-775

Bogdanowicz SM, Schaefer PW, Harrison RG (2000) Mitochondrial DNA variation among worldwide populations of gypsy moths, Lymantria dispar. Mol Phylogenet Evol 15:487-495

Boykin LM, Armstrong KF, Kubatko L, De Barro P (2012) Species delimitation and global biosecurity. Evol Bioinfo 8:1-37

Bradshaw CJA et al (2016) Massive yet grossly underestimated global costs of invasive insects. Nat Commun 7:12986

Chen F, Shi J, Luo Y-Q, Sun S-Y, Pu M (2013) Genetic characterization of the gypsy moth from China (Lepidoptera, Lymantriineae) using inter simple sequence repeats markers. PLoS ONE 8:e73017

Chen F, Luo Y, Keena MA, Wu Y, Wu P, Shi J (2015) DNA barcoding of gypsy moths from China (Lepidoptera: Erebidae) reveals new haplotypes and divergence patterns within gypsy moth subspecies. J Econ Entomol 109:366-374

deWaard JR, Mitchell A, Keena MA, Gopurenko D, Boykin LM, Armstrong KF et al (2010) Towards a global barcode library for Lymantria (Lepidoptera: Lymantriinae) tussock moths of biosecurity concern. PLoS ONE 5:e14280

Djoumad A, Nisole A, Zahiri R, Freschi L, Picq S, GundersenRindal DE, Sparks ME, Dewar K, Stewart D, Maaroufi H, Levesque RC, Hamelin RC, Cusson MC (2017) Comparative analysis of mitochondrial genomes of geographic variants of the gypsy moth, Lymantria dispar, reveals a previously undescribed genotypic entity. Sci Rep 7:14245

Garner KJ, Slavicek JM (1996) Identification and characterization of a RAPD-PCR marker for distinguishing Asian and North American gypsy moths. Insect Mol Biol 5:81-91

Harrison RG, ODell TM (1989) Mitochondrial DNA as a tracer of gypsy moth origins. In: Wallner WE, McManus KA (eds) Proceedings, Lymantriidae: a comparison of features of New and Old World tussock moths. USDA Forest Service, Northeastern Forest Experiment Station, Broomall, pp 265-273

Islam MS, Barr NB, Braswell WE, Martinez M, Ledezma LA, Molongoski J et al (2015) A multiplex real-time PCR assay for screening gypsy moths (Lepidoptera: Erebidae) in the United States for evidence of an Asian genotype. J Econ Entomol 108:2450-2457 
Kang TH, Lee K-S, Lee H-S (2015) DNA barcoding of the Korean Lymantria Hübner, 1819 (Lepidoptera: Erebidae: Lymantriinae) for quarantine inspection. J Econ Entomol 108:1596-1611

Kang TH, Han SH, Lee HS (2017) Genetic structure and demographic history of Lymantria dispar (Linnaeus, 1758) (Lepidoptera: Erebidae) in its area of origin and adjacent areas. Ecol Evol 7:9162-9178

Keena MA, Côté MJ, Grinberg PS, Wallner WE (2008) World distribution of female flight and genetic variation in $L y$ mantria dispar (Lepidoptera: Lymantriidae). Environ Entomol 37:636-649

Lacković N, Bertheau C, Stauffer C, Pernek M, Avtzis D (2015) Genetic split between coastal and continental populations of gypsy moth separated by Dinaric Alps. J Appl Entomol 139:721-726

Liebhold A, Mastro V, Schaefer PW (1989) Learning from the legacy of Léopold Trouvelot. Bull Entomol Soc Am 35:20-22

Milbury CA, Zhong Q, Lin J, Williams M, Olson J, Link DR, Hutchison B (2014) Determining lower limits of detection of digital PCR assays for cancer-related gene mutations. Biomol Detect Quant 1:8-22

Nealis VG (2002) Gypsy moth in Canada: case study of an invasive insect. In: Claudi R, Nantel P, Muckle-Jeffs E (eds) Alien invaders in Canada's waters, wetlands, and forests, pp 151-159

Nealis VG (2009) Still invasive after all these years: keeping gypsy moth out of British Columbia. For Chron 85:593-603

Newton CR, Graham A, Heptinstall LE, Powell SJ, Summers C, Kalsheker $\mathrm{N}$ et al (1989) Analysis of any point mutation in DNA. The amplification refractory mutation system (ARMS). Nucleic Acids Res 17:2503-2516

Owczarzy R, You Y, Groth CL, Tataurov AV (2011) Stability and mismatch discrimination of locked nucleic acid-DNA duplexes. Biochemistry 50:9352-9367

Pfeifer TA, Humble LM, Ring M, Grigliatti TA (1995) Characterization of gypsy moth populations and related species using a nuclear DNA marker. Can Entomol 127:49-58

Picq S, Keena M, Havill N, Stewart D, Pouliot E, Boyle B, Levesque RC, Hamelin RC, Cusson M (2018) Assessing the potential of genotyping-by-sequencing-derived single nucleotide polymorphisms to identify the geographic origins of intercepted gypsy moth (Lymantria dispar) specimens: a proof-of-concept study. Evol Appl 11:325-339
Pogue MG, Schaefer PW (2007) A review of selected species of Lymantria Hübner [1819] (Lepidoptera: Noctuidae: Lymantriinae) from subtropical and temperate regions of Asia, including the description of three new species, some potentially invasive to North America. USDA Forest Service, Washington

Qian L, An Y, Song J, Xu M, Ye J, Wu C et al (2014) COI gene geographic variation of gypsy moth (Lepidoptera: Lymantriineae) and a TaqMan PCR diagnostic assay. DNA Barcodes 2:10-16

Rutledge RG (2011) A Java program for LRE-based real-time qPCR that enables large-scale absolute quantification. PLoS ONE 6:e17636

Stewart D, Zahiri R, Djoumad A, Freschi L, Lamarche J, Holden D, Cervantes S, Ojeda DI, Potvin A, Nisole A, Béliveau C, Capron A, Kimoto T, Day B, Yueh H, Duff C, Levesque RC, Hamelin RC, Cusson M (2016) A multi-species TaqMan PCR assay for the identification of Asian gypsy moths (Lymantria spp.) and other invasive lymantriines of biosecurity concern to North America. PLoS ONE 11:e 0160878

USDA Pest alert (2016) Asian gypsy moth. APHIS 81-35-027 leaflet. USDA Animal and Plant Health Inspection Service, Riverside Park, MD. https://www.aphis.usda.gov/ publications/plant_health/content/printable_version/fs_ phasiangm.pdf. Accessed 6 Mar 2019

Wu Y, Molongoski JJ, Winograd DF, Bogdanowicz SM, Louyakis AS, Lance DR et al (2015) Genetic structure, admixture and invasion success in a Holarctic defoliator, the gypsy moth (Lymantria dispar, Lepidoptera: Erebidae). Mol Ecol 24:1275-1291

Zink FA, Tembrock LR, Timm AE, Farris RE, Perera OP, Gilligan TM (2017) A droplet digital PCR (ddPCR) assay to detect Helicoverpa armigera (Lepidoptera: Noctuidae) in bulk trap samples. PLoS ONE 12:e0178704

Zink FA, Tembrock LR, Timm AE, Gilligan TM (2018) A ddPCR assay for identification of Autographa gamma (Noctuidae: Plusiinae) in bulk trap samples. J Econ Entomol 111:1490-1495

Publisher's Note Springer Nature remains neutral with regard to jurisdictional claims in published maps and institutional affiliations. 